\title{
A MICROSOFT EXCEL TÁBLÁZATKEZELÖ DÖNTÉSTÁMOGATÁS SORÁN HASZNOS SZOLGÁLTATÁSAI
}

\author{
Hampel György
}

\begin{abstract}
Absztrakt: Ma már szinte nincs olyan szervezet, amelynek számítógépén ne lenne táblázatkezelő. A táblázatkezelő egyfajta döntéstámogató rendszernek tekinthető. Jelen cikk célja áttekinteni a Microsoft Excel 365 táblázatkezelő cikk írásakor aktuális változatában elérhető fontos szolgáltatásokat, amelyek egy szervezet vezetője számára hasznosnak bizonyulhatnak a döntési folyamat során. Az Excel táblázatkezelő alapesetben is kínál olyan adatmanipulációs szolgáltatásokat, amelyek alkalmassá teszi a döntéstámogatásra; ezek az adatok beolvasása, szürés és rendezés, feltételes formázás és számformátumok alkalmazása, lehetőségelemzés (célérték keresése, esetvizsgáló, adattábla), kimutatás és diagram készítése. Több olyan bővítmény (add-in), amely alapbeállítás szerint nincs bekapcsolva; ezek közül a legfontosabbak az Analysis ToolPak, a Solver és a Microsoft Power Pivot for Excel. Ezek a kiegészítő szolgáltatások számos további hasznos funkciót tartalmaznak a döntéshozó számára a döntéstámogatáshoz. Egy korszerü táblázatkezelő szolgálatatásainak ismerete előnyt biztosíthat a szervezet döntéshozója számára, mert a programban biztosított eszközökkel a hagyományos (többnyire ösztönökre, intuíciókra hagyatkozó) döntések helyett adatokra, információkra alapozott jobb döntések születhetnek.
\end{abstract}

\begin{abstract}
Nowadays there is hardly any organization that does not have a spreadsheet program on its computer. The spreadsheet can be considered as a kind of decision support system. The purpose of this article is to provide an overview of the important features that are available in the current version of the Microsoft Excel 365 that may be useful to an organization manager during the decision-making process. By default, Excel Spreadsheet also offers data manipulation features that make it suitable for decision support; these include data retrieval, sorting and filtering, the use of number formats and conditional formatting, what-if analysis (goal seek, scenario manager, data table), pivot table and charts. There are some add-ons that are not enabled by default; the most important of these are Analysis ToolPak, Solver and Microsoft Power Pivot for Excel. These additional features include a number of additional useful features for the decision maker to support decision making. Knowledge of the possibilities of a modern spreadsheet can provide an advantage to the decision-maker of the organization, because with the tools provided in the program, better decisions based on data and information can be made instead of the traditional (mostly instinct- and intuition-based) decisions.
\end{abstract}

Kulcsszavak: Microsoft Excel, döntés, döntéstámogatás

Keywords: Microsoft Excel, decision, decision support

\section{Bevezetés}

Az információs társadalomban minden szellemi munkát végzőtől elvárt az informatikai ismeretek birtoklása, ami alapvetően a számítógép és programjainak kezelését és megértését, az elektronikus szolgáltatások igénybevételének képességét jelenti. Emellett az információs müveltség birtoklása is nélkülözhetetlen, ami azt jelenti, hogy a munkavállaló (alkalmazott vagy vezető):

- felismeri az információszükségletet;

- azonosítja az adott probléma megoldásához szükséges információt;

- megtalálja a szükséges információt;

- értékeli a megtalált információt; 
- hatékonyan használja fel az információt az adott probléma megoldására (American Library Association, 1989).

Valamilyen táblázatkezelő programot ma már sokan ismernek és használnák legalább alapszinten, ha dolgoznak számítógéppel és a munka része valamilyen adatfeldolgozási, adatmanipulációs vagy éppen adatmegjelenítési tevékenység. Ma már szinte nincs olyan szervezet, amelynek számítógépén ne lenne táblázatkezelő, ami az irodai programcsomag egyik alapkelléke a szövegszerkesztő és a bemutatókészítő mellett. A táblázatkezelő egyfajta döntéstámogató rendszernek (is) tekinthető, a segítségével készíthetők akár döntési problémák megoldását támogató alkalmazások (Kacsukné-Kiss, 2009).

Jelen cikk célja áttekinteni a Microsoft Excel 365 táblázatkezelő 64 bites, magyar nyelvü, a cikk írásakor aktuális (verzió: 2105, 2021. június) változatában elérhető fontos szolgáltatásokat, amelyek egy szervezet vezetője számára is hasznosnak bizonyulhatnak a döntési folyamat során.

\section{Anyag és módszer}

Az informatikai eszközrendszer egy szervezet vezetése számára akkor hasznos, ha megfelelő adatokat összegyüjtve, majd az adatokat feldolgozva - információvá, vállalati tudássá alakítva - és megjelenítve hatékonyan támogatja a döntéshozatalt (Juhász, 2015). A döntéshozatalt a szakirodalom a problémamegoldás szinonimájának tekinti, a döntéselmélet a problémamegoldás elméletébe ágyazódva jelenik meg (Kindler, 2006). Egy probléma megfogalmazható, mint a jelenlegi, észlelt állapot megváltoztatását célzó igény, és irányulhat akár a jelenlegi állapot megtartására, akár egy még kívánatosabb állapot elérésére. A döntéshozatal aktív szereplöje az ember, aki észlelve a környezete bizonyos problémáit, meg akarja azokat oldani (Sántáné et al., 2008). A kívánatos helyzet létrehozása, vagy legalább az afelé való elmozdulás döntéssel, majd pedig a döntések végrehajtásával és ellenőrzéssel érhető el (Horváth, 2002).

A döntések sokféleképpen csoportosíthatók, részletes összefoglalót ad Hanyecz (1994):

- programozhatóság szerint beszélhetünk programozott és programozatlan döntésekröl;

- tárgy szerint léteznek piaci-gazdasági, müszaki és szervezési döntések;

- időhatárok szerint megkülönböztethetünk rövid és hosszú távú döntések;

- jelleg szerint lehetnek kezdeményezö és alkalmazkodási döntések;

- szervezeti helyzet szerint vannak átruházható és nem átruházható döntések;

- döntéshozók száma szerint egyéni és csoportos döntéseket különböztethetünk meg;

- a vezetési szint szerint stratégiai (felső), taktikai (középső) és operatív (alsó szintü) döntések lehetségesek egy szervezetben;

- előszabályozottság szerint beszélhetünk egyfázisú (egy lépésből álló), vagy többfázisú (több döntésből álló) döntésekről;

- módszer szerint léteznek hagyományos és modern (azaz korszerủ elemzési módszereket és informatikai támogatást alkalmazó) döntések. 
A szervezetben a döntések jellemzően nem egymástól elkülönülve, hanem egymásra hatva születnek, sokkal inkább beszélhetünk döntések struktúrájáról, ahol az egyes döntési feladatokat össze kell kapcsolni és együttesen kell kezelni (Hanyecz, 1995).

A döntés értelmezése lehet statikus (egy pillanatnyi aktus), vagy dinamikus: Az első lépés a döntési helyzet azonosítása (helyzetfelismerés, helyzetfelmérés, helyzetelemzés); ezt követi a döntéselőkészítés (célkitüzés, kritériumok meghatározása, alternatívák kidolgozása és értékelése); majd az alternatívák közüli választás következik, ami tulajdonképpen a döntés; végül a sort a döntés végrehajtásának ellenőrzése zárja (Chikán, 1978). Az előbbi egy lehetséges felosztása a döntési folyamatnak, léteznek ettől kisebb-nagyobb mértékben eltérö megközelítések is, de az imént említett fázisok, lépések, amelyek nem szekvenciálisak, hanem visszahatnak egymásra, használható közelítést ad a döntésről, mint folyamatról. Korszerü döntéshozatal esetén valamennyi fázisban szerepet kaphatnak a döntéshozatalt segítő különböző számítógépes alkalmazások.

A döntéstámogató rendszer számítógépes eszközök összessége, amelyek különböző döntési modellek, adatbázisok, valamint a döntéshozó ítélőképességének segítségével interaktív módon segíti a döntéshozatalt. Egyrészt információt szolgáltat a vezetőknek rendszeres vagy ad-hoc jelentések formájában, nagy mennyiségü adatot kezelve és feldolgozva, másrészt modellezési képességekkel rendelkezik, így különböző matematikai és analitikai modellekkel elemzéseket elörejelzéseket készít és javaslatokat tesz egy adott döntési probléma megoldására (Kacsukné-Kiss, 2009).

Ahogy már említettem, a táblázatkezelő tekinthető egyfajta döntéstámogató rendszernek. Ezek a programok kezdeti megjelenésükkor (VisiCalc: 1979; Lotus 12-3: 1983, Microsoft Excel: 1985, Borland Quattro: 1988) még nem voltak alkalmasak hatalmas adattömeg kezelésére és szolgáltatásaik jelentősen elmaradtak a mai táblázatkezelő alkalmazások képességeihez képest (Kepos, 1994; PowerKaparthi, 2003; Power, 2004; Computer History, n. a.; WinWorld, n. a.). Jelenleg ismertebb táblázatkezelő programok közé tartozik: Microsoft Excel, Apple Numbers, Google Sheets, Quip, EtherCalc, Zoho Sheets, LibreOffice, Apache OpenOffice Calc, Smartsheet, Airtable (Pincher, 2021).

A táblázatkezelők az irodai alkalmazások körébe tartoznak és ma már jellemzően egy több alkalmazásból álló alkalmazói programcsomag részét képezik. Az alkalmazás (alkalmazói szoftver, felhasználói program) a végfelhasználó számára valamilyen feladat végrehajtásának elősegítésére készített számítógépprogram. Az irodai alkalmazások olyan programok, amelyek kifejezetten irodákban felmerülő feladatok megoldásában nyújtanak hatékony segítséget. A 1980-as években jellemző karakteres felhasználói felületet felváltotta a grafikus felhasználói felület és a WYSIWYG (What You See Is What You Get: azt kapod [nyomtatásban], amit látsz [a képernyőn]) rendszerü müködés (Hampel-Heves, 2019). 
A táblázatkezelő alapszolgáltatásai az alábbiak (Hampel-Heves, 2019):

- adatok beolvasása (importálása) a saját formátum mellett számos formátumú állományból, így szövegfájlból, helyi és online adatbázis táblákból akár közvetlenül, akár ODBC API-n keresztül (Open Database Connectivity Application Programming Interface - nyílt adatkapcsolat alkalmazásprogramozási felület), vagy adatbázis-lekérdezésből;

- adatok rendszerezése, felsorolások, egyszerü táblák és kimutatások (pivottábla) létrehozása;

- adatok egy vagy több szempont szerinti rendezése, szürése;

- egyéni, valamint elöre elkészített sablonokkal történő formázás, továbbá bizonyos feltételeknek megfelelő (vagy éppen nem megfelelö) adatok kiemelése számformázással és feltételes formázással;

- adatmanipuláció matematikai és logikai müveletekkel, valamint rengeteg beépített matematikai, statisztikai, mérnöki, pénzügyi stb. függvény felhasználásával;

- elemzés a matematikai-statisztika módszereivel, szimuláció és modellezés biztosítása - egyes funkciók eléréséhez beépített bővítmények bekapcsolása szükséges (például: Analysis ToolPak, Solver, Power Pivot), továbbá rendelkezésre állnak ingyenes és kereskedelmi forgalomban elérhetö bővítmények is;

- adatok szemléletes ábrázolása különböző diagramtípusokkal, az oszlop-, vonal-, kör-, sáv-, terület-, pont-, térkép-, árfolyam-, felület-, sugár-, fatérkép, többszintü gyürü, hisztogram, doboz-, vízesés, tölcsér és kombinált diagram az alapszolgáltatáshoz tartozik;

- adatok (munkalapok) mentése vagy exportálása és publikálása (megosztása) számos formátumban;

- munkaterület egészének, vagy meghatározott részének, illetve a diagramnak a kinyomtatása.

\section{Az Excel szolgálatásai}

Az Excel táblázatkezelő alapesetben is kínál olyan adatmanipulációs szolgáltatásokat, amelyek alkalmassá teszi a döntéstámogatásra (lásd: előző fejezetben a szolgáltatások felsorolása). Néhány fontosabb szolgáltatás részletesebben:

- Adatok beolvasása: Számos információs rendszer kínál arra lehetőséget, hogy az adatait valamilyen módon hozzáférhetővé tegye más rendszerek számára. Ennek legegyszerübb formája a szöveg- (vagy egyéb, sok adatkezelő program által támogatott formátumú) fájlba mentés, vagy a rendszer adatbázisához való közvetlen hozzáférés (korlátozások mellett). Az Excel képes az információs rendszerek előbbi módon közzétett adatait beolvasni, feltéve, hogy az adatok mennyisége belefér a munkafüzet munkalapjai által meghatározott keretekbe - nagyobb adatmennyiséghez használható a Microsoft Power Pivot bővítmény. Az 1. ábra részletet mutat az adatimportálásra szolgáló menüből. 
- Szürés, rendezés: A munkalapon lévő adatok egy vagy több szempont szerint szürhetők, rendezhetők. Akár logikai kifejezésekkel összekapcsolt, összetett keresési feltételek is megadhatók, ezzel segítve az adathalmazból az adott helyzetben, a döntéshez szükséges releváns információ kiválogatását (2. ábra).

- Feltételes formázás és számformátumok alkalmazása: Az előre elkészített témákkal, táblázat- és cellastílusokkal egységes kinézetű munkalapok, táblázatok készíthetök. Emellett szükség lehet bizonyos cellák megadott feltételektől függő, a többi cellától eltérő megjelenítésére (3. ábra).

- Lehetőségelemzés - Célérték keresése: Ismert eredményhez tartozó bemeneti értékek kereshetők, egyváltozós bementi értékekkel használható szolgáltatás (4. ábra).

- Lehetőségelemzés - Esetvizsgáló: Ezzel a szolgáltatással különböző értékcsoportok (alternatívák) hozhatók létre és menthetők el „eset”-ként. Az esetek között váltva tekinthetök meg az esetektől függő eredmények (5. ábra). Összefoglaló jelentés is készíthető, amely az összes eset adatait és következményeit tartalmazza.

- Lehetőségelemzés - Adattábla: Egy vagy két változó értékei alapján egy táblázatot ad eredményül, amelyet a változók értékeivel kalkulált kifejezés eredményével tölt fel (6. ábra).

- Kimutatás: Adatlistából csoportosító, vagy kombinációs (kontingencia) táblázatok készíthetők, így egy hatalmas adathalmaz könnyen áttekinthető információt hordozó táblázattá konvertálható. Tartalmazhat egy vagy akár több szempont szerint csoportosított darabszámot, összesítést, átlagot, legkisebb és legnagyobb értéket stb. A megjelenített adatok további szempontok szerint szürhetök (7. ábra). Az adatok százalékos formában is megjeleníthetők, ezzel jobban érzékeltetve az arányokat (sorösszeg \%-a, oszlopösszeg \%-a, végösszeg \%-a stb.)

- Diagram: Adatsorok, kimutatások sok esetben még szemléletesebben ábrázolhatók a helyesen megválasztott diagram segítségével (8. ábra). Abban az esetben, ha a diagram készítése előtt kijelöljük az ábrázolandó cellákat, az Excel javaslatot tesz diagramtípusra. A diagramok számos módon tesztre szabhatók, így némi kreativitással az adatok igen látványos ábrázolására van lehetőség. A diagram egy speciális változata, az ún. értékgörbe, akár egyetlen cellában kiválóan alkalmas trendek jelzésére. Az ábrázolandó adatsorhoz alkalmazható diagramtípusok kiválasztásához az interneten is találunk magyarázattal kiegészített segítséget, érdemes például szétnézni a „from Data to Viz” weboldalon is (https://www.data-toviz.com/). 


\section{1. ábra: Adatok beolvasása (importálása) létező forrásokból (részlet)}

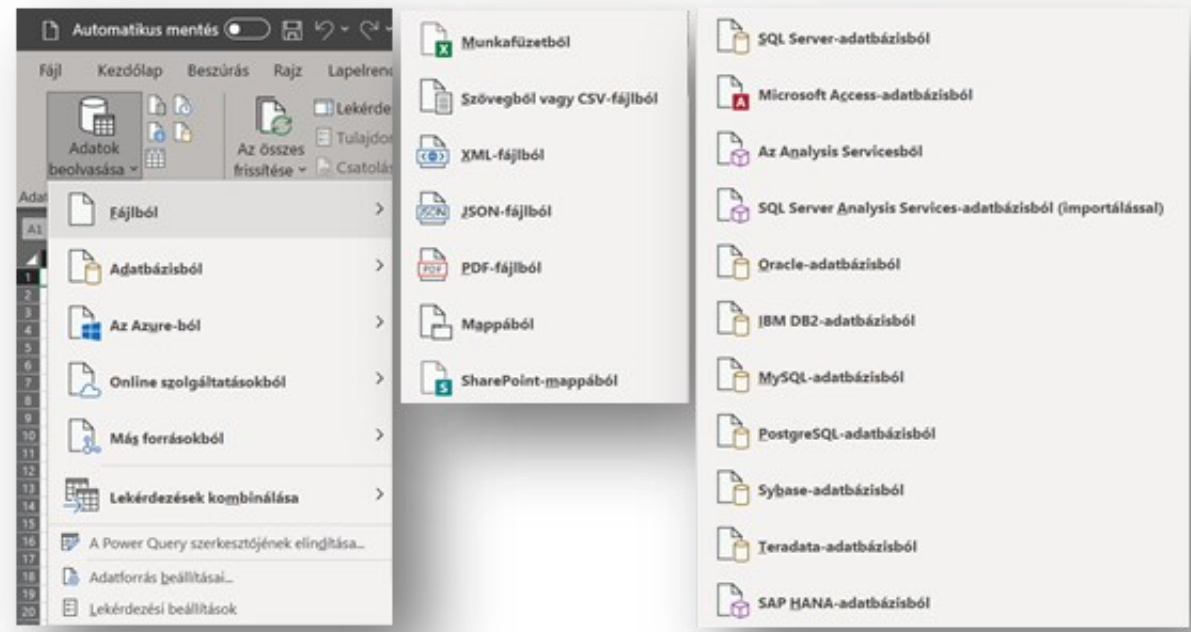

Elérés: Adatok/Adatok beolvasása és átalakítása menü.

Forrás: Microsoft Excel képernyőmentés alapján saját szerkesztés

\section{2. ábra: Adatok rendezése és szürése}

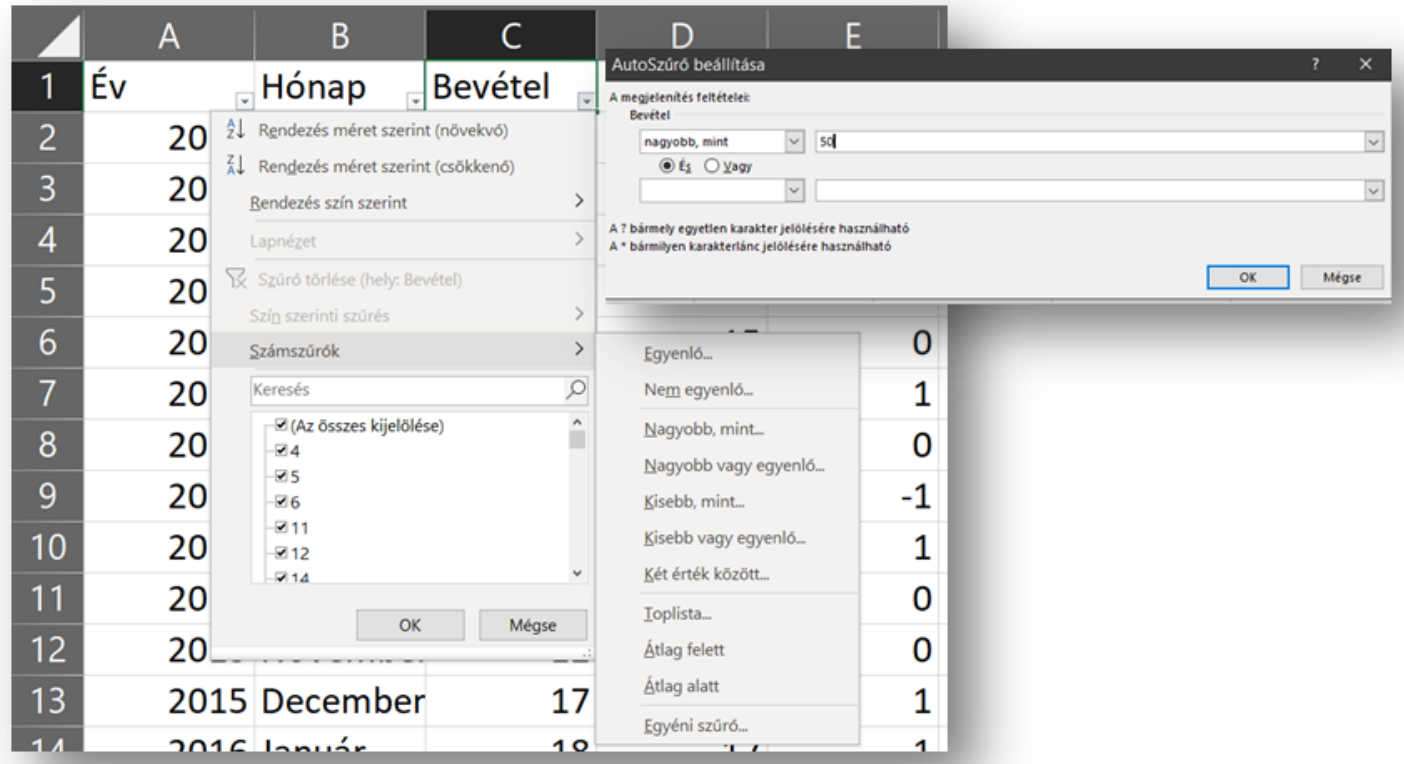

Elérés: Adatok/Rendezés és szürés menü.

Forrás: Microsoft Excel képernyőmentés alapján saját szerkesztés 


\section{3. ábra: Feltételes formázás és számformátum az adatok kiemelésére}

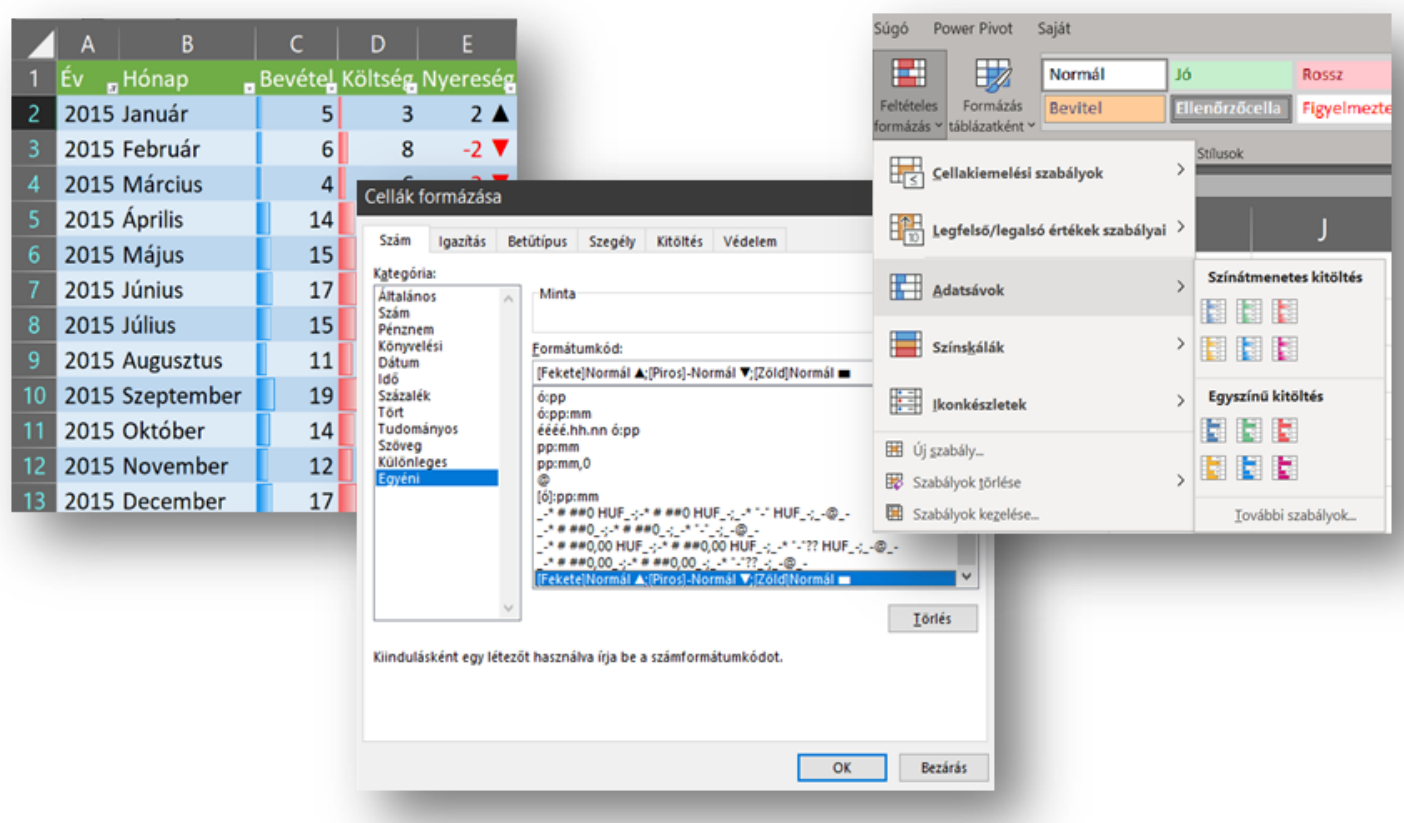

Elérés: Kezdőlap/Szám és Kezdőlap/Stílusok menü.

Forrás: Microsoft Excel képernyőmentés alapján saját szerkesztés

\section{4. ábra: Célérték keresése}

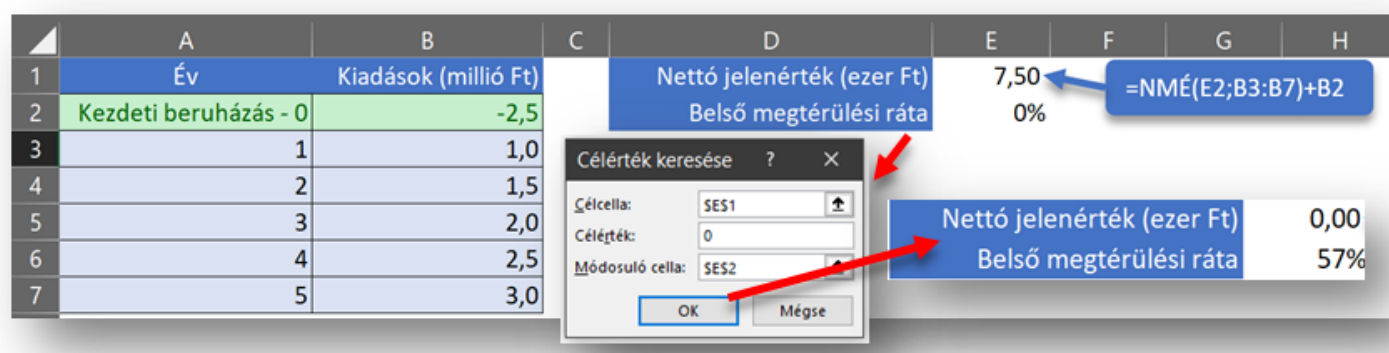

Elérés: Adatok/Lehetőségelemzés/Célértékkeresés menü.

Forrás: Microsoft Excel képernyőmentés alapján saját szerkesztés 


\section{5. ábra: Esetvizsgáló}

\begin{tabular}{|c|c|c|c|c|c|c|c|c|c|}
\hline & & & & & & & \multirow{2}{*}{\multicolumn{2}{|c|}{$\begin{array}{l}\text { Qotimista becslés } \\
\text { Pesszimista becslés }\end{array}$}} & \multirow{3}{*}{$\begin{array}{l}\text { Hozzáadás... } \\
\text { Iorlés }\end{array}$} \\
\hline$\Delta$ & A & B & C & D & E & $\mathrm{F}$ & & & \\
\hline 1 & & \multicolumn{3}{|c|}{ Tényadatok } & \multicolumn{2}{|r|}{ Tervadatol } & & & \\
\hline 2 & & 2018 & 2019 & 2020 & 2021 & 2022 & & & Szerkesztés... \\
\hline 3 & Termékértékesítés bevétele & 4950000 & 5197500 & 5405400 & 5675670 & 5959454 & & & \multirow[b]{2}{*}{ Egyesités... } \\
\hline 4 & Szolgáltatás bevétele & 1300000 & 1391000 & 1474400 & 1548120 & 1625526 & & & \\
\hline 5 & Bevétel & 6250000 & 6588500 & 6879800 & 7223790 & 7584980 & & 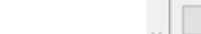 & Lelentés... \\
\hline 6 & Értékesítési költségek & 2800500 & 3024500 & 3130400 & 3033992 & 3109842 & & & \\
\hline 7 & Egyéb költségek & 1150000 & 1184500 & 1279300 & 1532431 & 1489863 & \multirow{3}{*}{$\begin{array}{l}\text { Változó cellä́c } \\
\text { Megjegyzés: }\end{array}$} & SES13:SGS15 & \\
\hline 8 & Költség & 3950500 & 4209000 & 4409700 & 4566423 & 4599705 & & \multirow{2}{*}{\multicolumn{2}{|c|}{$\begin{array}{l}\text { Készitette: Hampel György } \\
\text { Módositotta: Hampel György }\end{array}$}} \\
\hline$\frac{9}{10}$ & Nyereség & 2299500 & 2379500 & 2470100 & 2657367 & 2985275 & & & \\
\hline 11 & \multirow[t]{2}{*}{ Ráták és becslések } & \multicolumn{3}{|c|}{ Tényadatok } & \multirow{2}{*}{\multicolumn{3}{|c|}{ 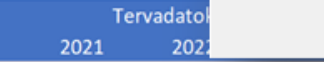 }} & \multirow[b]{2}{*}{ Megjelentites } & \\
\hline 12 & & 2018 & 2019 & 2020 & & & & & Bezáras \\
\hline 13 & Bevétel növekedési ütem & - & $5,4 \%$ & $4,4 \%$ & $5,0 \%$ & $6,0 \%$ & $7,0 \%$ & & \\
\hline 14 & Nyereség & $36,8 \%$ & $36,1 \%$ & $35,9 \%$ & $38,0 \%$ & $39,0 \%$ & $38,0 \%$ & & \\
\hline 15 & Egyéb költségek & - & - & - & $27 \%$ & $25 \%$ & $23 \%$ & & \\
\hline
\end{tabular}

Elérés: Adatok/Lehetőségelemzés/Esetvizsgáló menü.

Két beállított eset közül az egyiktől függő alternatíva adatai táblázatban.

Forrás: Microsoft Excel képernyőmentés alapján saját szerkesztés

\section{6. ábra: Adattábla két változóval}

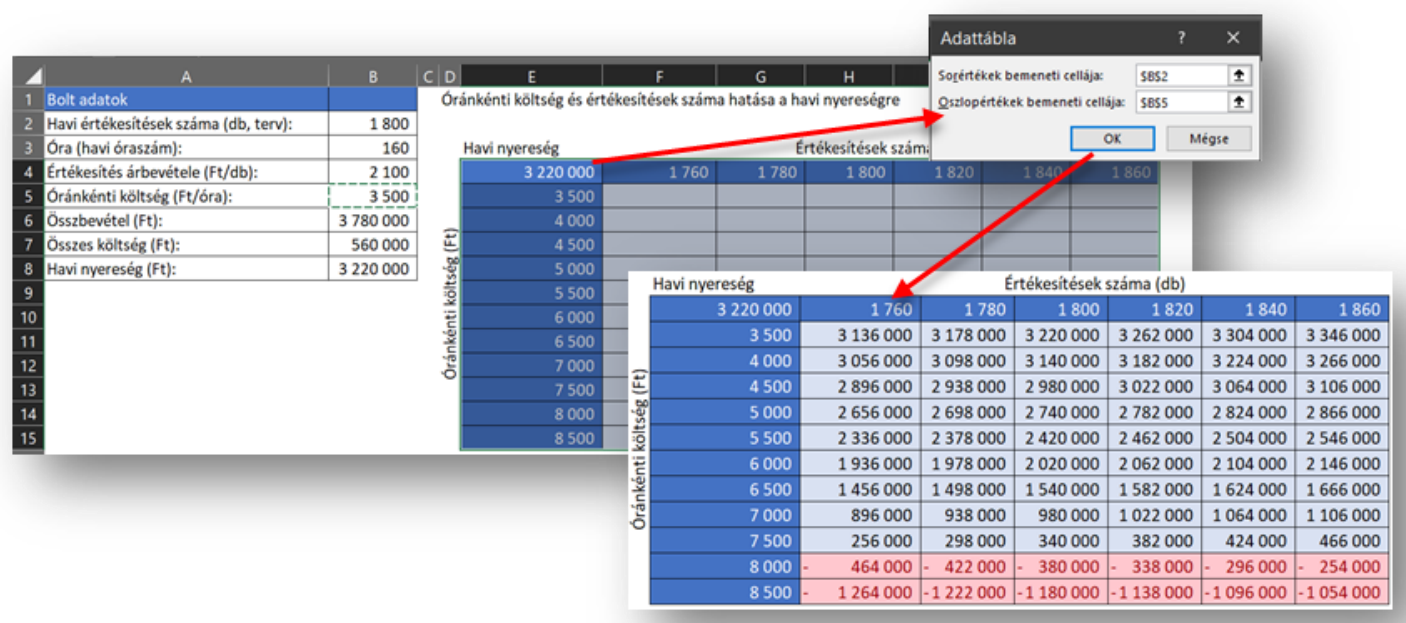

Elérés: Adatok/Lehetőségelemzés/Adattábla menü.

Forrás: Microsoft Excel képernyőmentés alapján saját szerkesztés 


\section{7. ábra: Kimutatás szeletelővel (szürővel) kiegészítve}

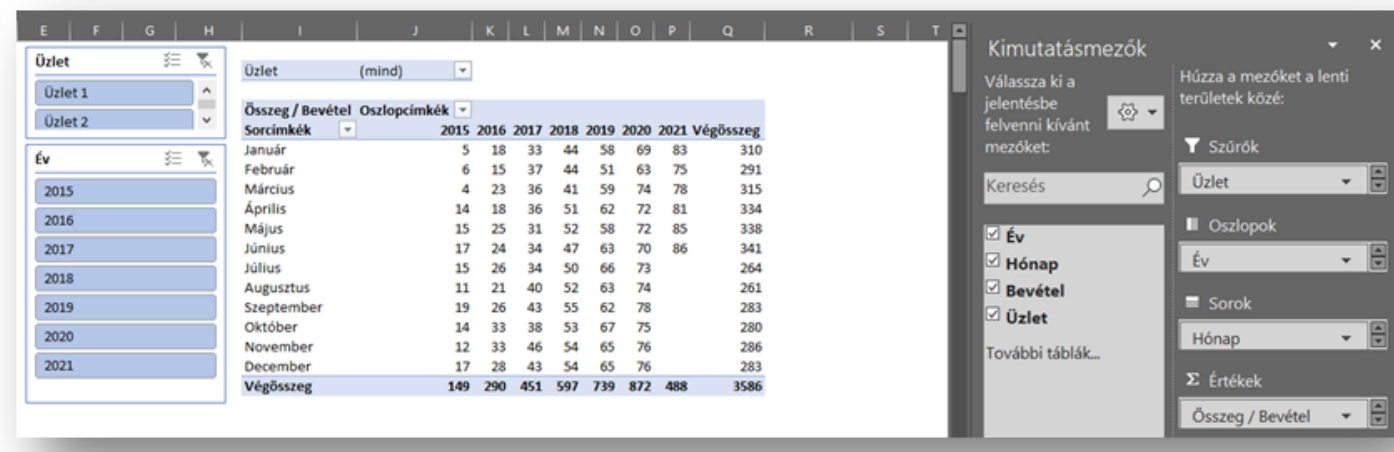

Elérés: Beszúrás/Kimutatás menü, Kimutatástáblázat elemzése menü.

Forrás: Microsoft Excel képernyőmentés alapján saját szerkesztés

\section{8. ábra: Alap diagramtípusok és formázott diagram példák}

\begin{tabular}{|c|c|}
\hline 凹n & Oszlop \\
\hline 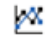 & Vonal \\
\hline Q & Kör \\
\hline 色 & Sáv \\
\hline$\aleph$ & Terület \\
\hline$\because \because:$ & Pont $(X Y)$ \\
\hline Q & Térkép \\
\hline 瀻 & Árfolyam \\
\hline 年 & Felület \\
\hline 弗 & Sugár \\
\hline 四 & Fatérkép \\
\hline (98) & Többszintũ gyũrũ \\
\hline 监 & Hisztogram \\
\hline 南 & Dobozdiagram \\
\hline 叫 & Vízesés \\
\hline 吕 & Tölcsér \\
\hline 归 & Kombináltak \\
\hline
\end{tabular}
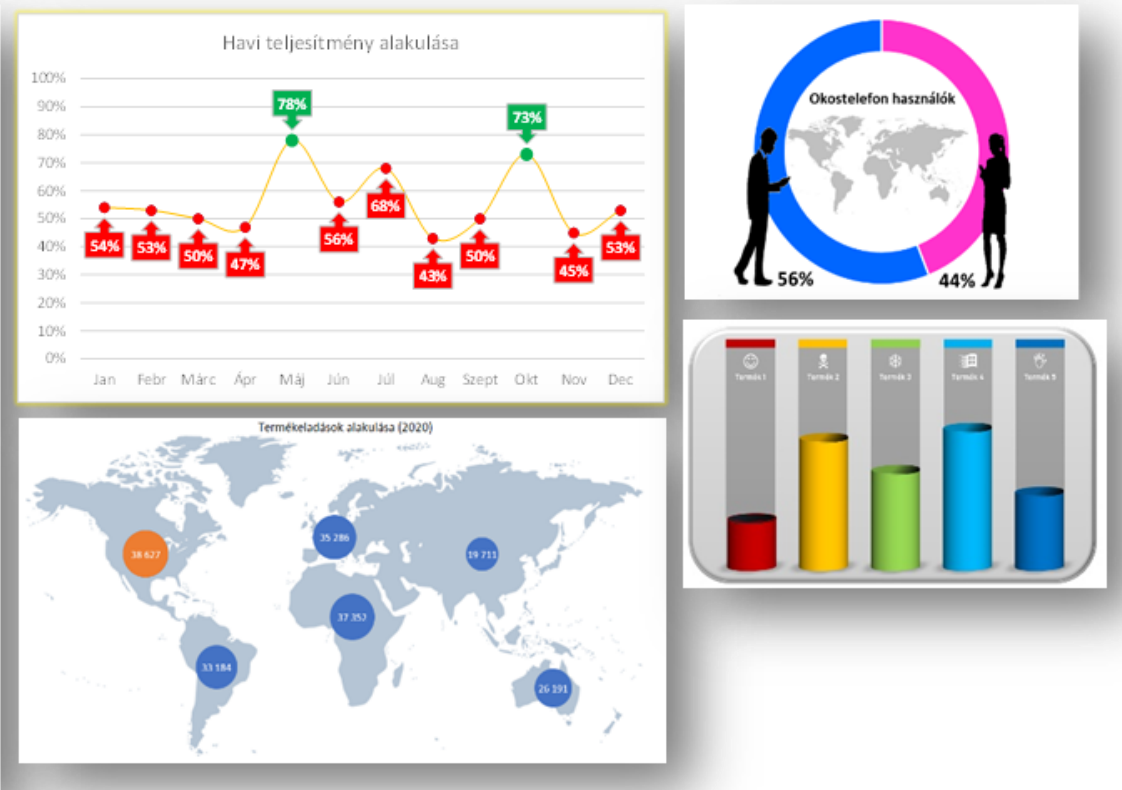

Elérés: Beszúrás/Diagramok menü, Diagramtervezés menü.

Forrás: saját szerkesztés, a példák Youtube4 (2018), Youtube1 (2016), Youtube3 (2018), Youtube2 (2020) alapján

Az Excel táblázatkezelő több olyan bővítményt tartalmaz, amely alapbeállítás szerint nincs bekapcsolva: Analysis ToolPak, Solver és Microsoft Power Pivot for 
Excel stb. Ezeknek a kiegészítő szolgáltatásoknak az élesítésével számos további hasznos funkció adódik a felhasználó számára a döntések támogatásához:

- Analysis ToolPak: A táblázatkezelő adatelemző bővítménye, amely a már beépített függvényeket hasznosítja. Egyetlen munkalapon található bonyolult statisztikai vagy mérnöki elemzésekhez alkalmazható és az eredmények táblázatos formában és - ahol indokolt - diagramon jelennek meg. A bővítmény a bekapcsolása után az Adatok menüben látható. Az elérhető szolgáltatásokhoz lásd: 9. ábra.

- Solver: Lehetőségelemzésre alkalmas bővítmény, amelynek segítségével egy célértékcellában lévő képlet maximális, minimális vagy megadott értéke kereshető meg korlátozások (peremfeltételek) megadása mellett (10. ábra). A bővítmény a döntési változók (változócellák) csoportját használja fel, amelyek a képletek kiszámításához használhatók a célérték- vagy a korlátozáscellában. A program úgy módosítja a döntési változócellák értékeit, hogy azok megfeleljenek a korlátozáscella feltételeinek és egyúttal a célértékcellához a kívánt eredmény (maximum, minimum, vagy megadott érték) álljon elö.

- Microsoft Power Pivot for Excel: A bővítményben - amely külön ablakban fut -, hatalmas mennyiségü adatot tartalmazó adatmodellek készíthetők, amelyek az adatbáziskezelőkben megszokott relációs modell szerinti táblázatokat és kapcsolatokat tartalmazhatnak (11. ábra). A táblák alapadatai kiegészíthetők a DAX (Data Analysis Expression) képletkifejező nyelven írt további oszlopokkal, amelyek függvények, operátorok és értékek segítségével végeznek összetett számításokat és lekérdezéseket a kapcsolódó táblákban lévő adatokon, valamint a táblázatos adatmodellekben található oszlopokon. (A folyamatosan bővülő DAX függvényekről és azok használatáról a https://docs.microsoft.com/hu-hu/dax/dax-overview weboldalon található leírás). Az így létrehozott adatmodellekből kimutatások (pivot táblák) készíthetők, amelyek az Excelben megszokott kimutatásokat DAX függvényekkel létrehozott ún. mértékekkel egészíthetik ki. 


\section{9. ábra: Analysis ToolPak menü}

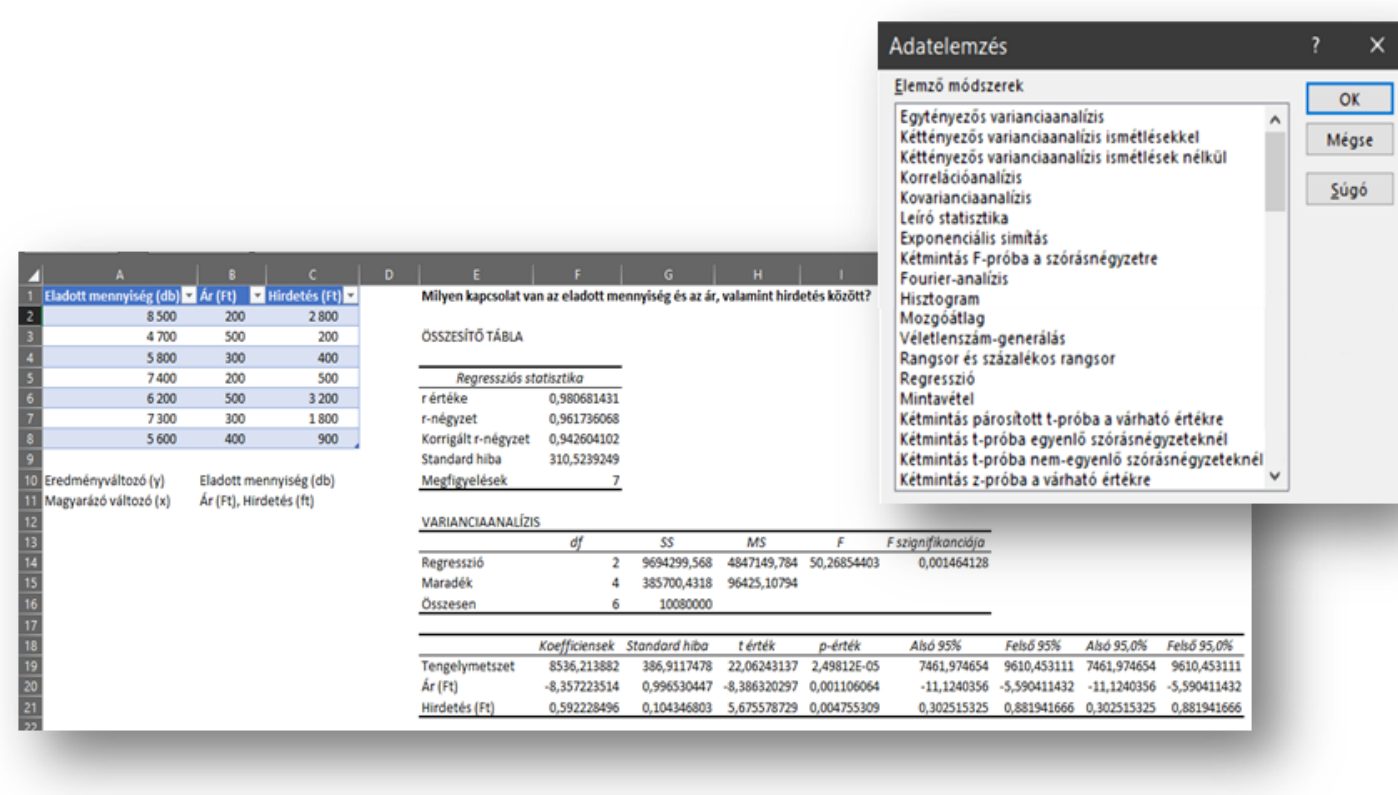

Elérés a bővítmény bekapcsolása után: Adatok/Elemzés/Adatelemzés menü. A felső részen az elérhető elemző módszerek listája látható. Az alsó rész egy regresszió analízis eredményét tartalmazza. A táblázatból kiolvasható az elkészült modell illeszkedése, használhatósága (szignifikanciája), a modell elemei stb. Forrás: Excel képernyőmentés alapján saját szerkesztés

\section{0. ábra: A Solver}

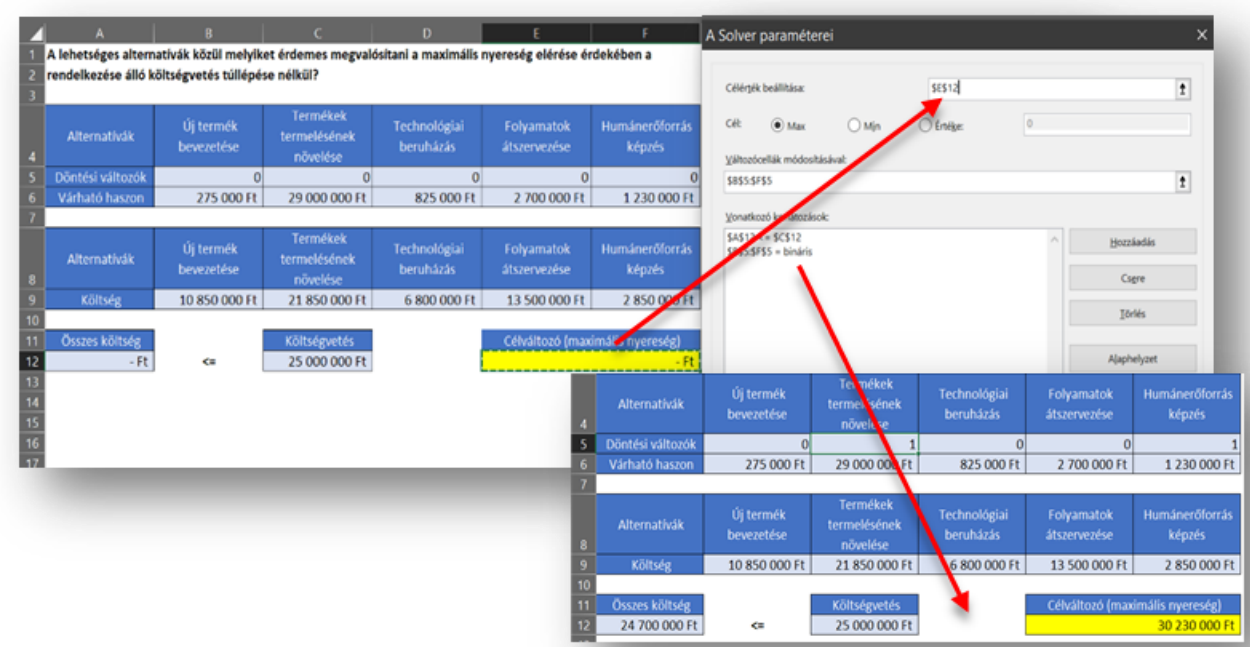

Elérés a bővítmény bekapcsolása után: Adatok/Elemzés/Solver menü. Az ábrán a kiinduló állapot és a beállítások (felső rész), valamint a futtatás eredménye (alsó rész) látható.

Forrás: Microsoft Excel képernyőmentés alapján saját szerkesztés 


\section{1. ábra: A Power Pivot}

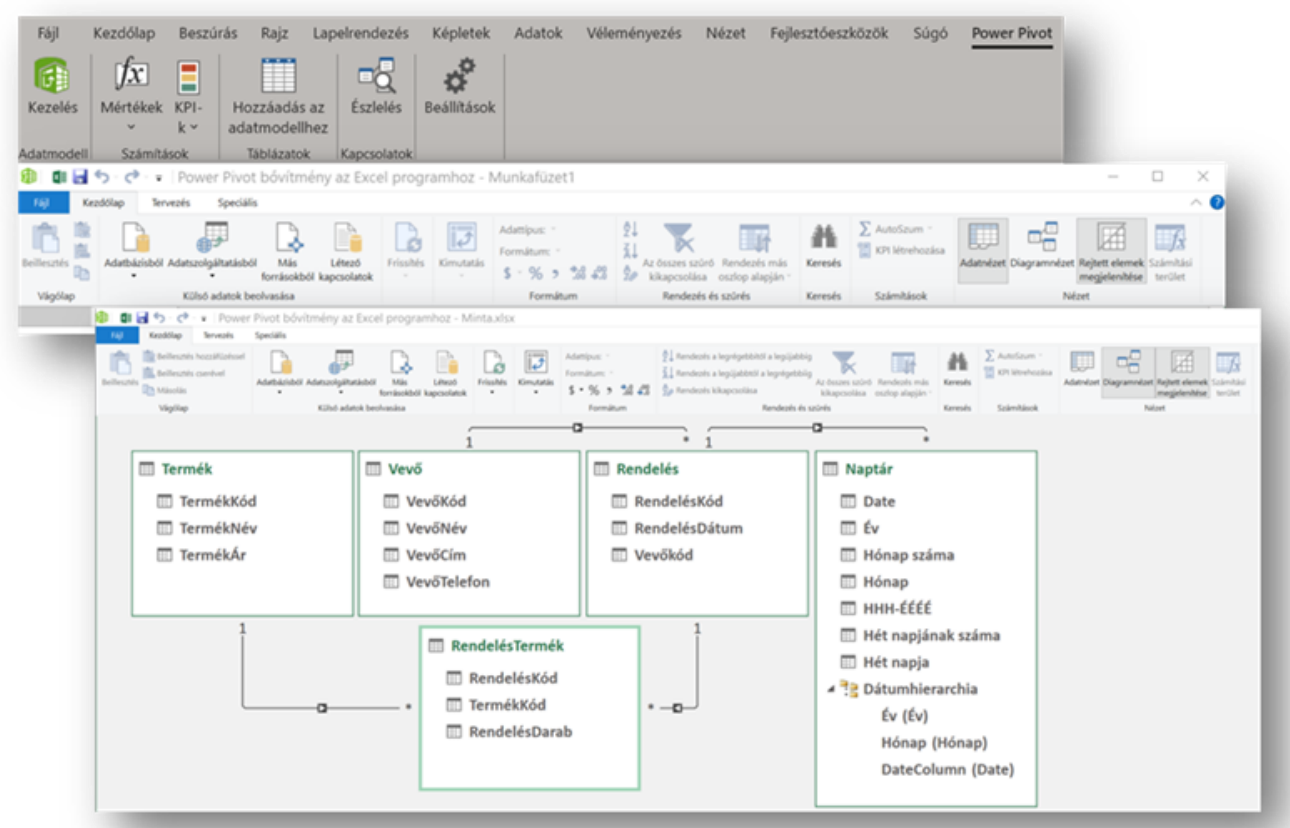

Elérés a bővítmény bekapcsolása után: Power Pivot menü (ábra felső része). A Power Pivot/Kezelés menüvel indítható Power Pivot ablak menüje (középen). A Power Pivot Diagramnézete (alsó rész).

Forrás: Microsoft Excel és Power Pivot képernyőmentés alapján saját szerkesztés

A munkalapon található táblázatok, diagramok és objektumok (pl. alakzatok, makrók) felhasználásával „dashboard” hozható létre. A dashboard (angol kifejezés) egy olyan egyoldalas (egyképernyős) vizuális felületet jelöl, amely alkalmas arra, hogy segítségével a felhasználó első ránézésre figyelemmel kísérje a legfontosabb céljainak, elvárásainak megvalósulását (Few, 2006; Kövári, 2017). Mivel egyetlen oldalról van szó, a dashboard csak a legfontosabb KPI-ket (Key Performance Indicator: fö teljesítménymutató) tartalmazhatja. Sokszor nem olyan könnyü megtalálni azt a néhány lényeges mutatót, ami fontos a döntéshozó számára és valóban elfér egy oldalon. A jó dashboard mindig a célok, elvárások megvalósulását mutatja - ennyiben különbözik a jelentésektől (riportoktól); nem az a célja tehát, hogy egy állapotot mutasson be, hanem az, hogy az állapot céltól való eltérését hangsúlyozza és ezzel kényszerítse cselekvésre a döntéshozót. Pénzügyi adatokat tartalmazó Dashboard látható a 12. ábrán. 


\section{2. ábra: Excel Dashboard}

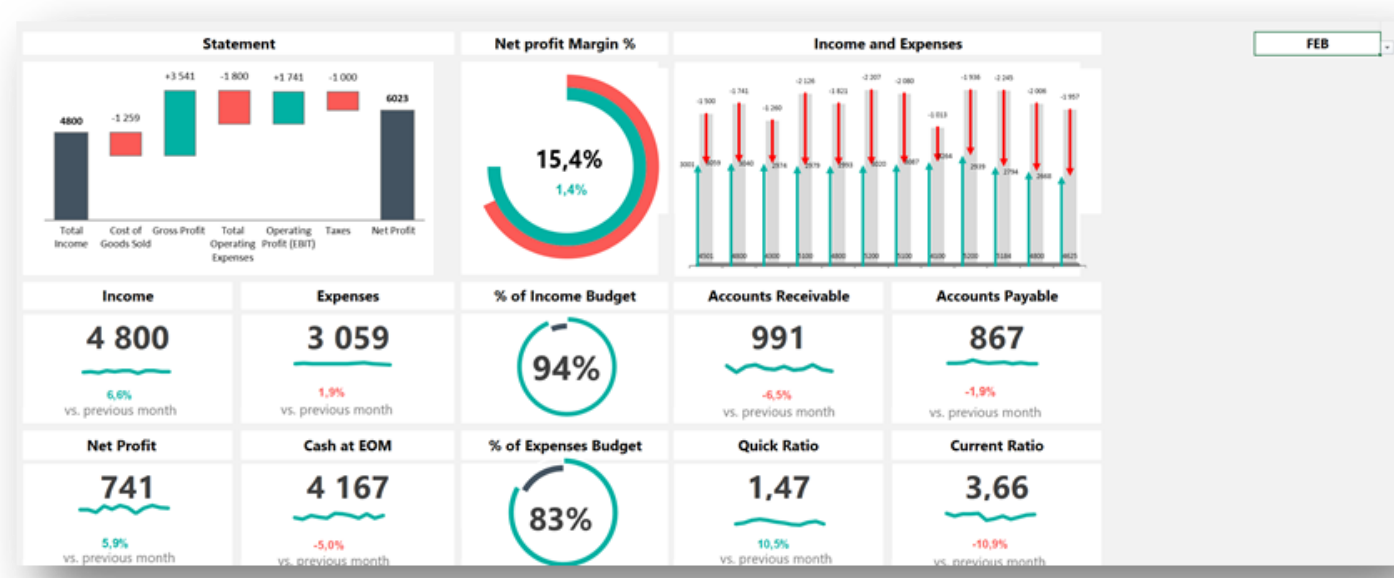

Forrás: ExcelDashboardSchool.com, 2020

\section{Záró gondolatok}

Ma már minden szervezeti vezető számára létkérdés, hogy képes legyen a döntések meghozatalához és a végrehajtás ellenőrzéséhez nélkülözhetetlen adatokat értelmezni, információvá alakítani. Ehhez hatékony segítséget nyújthatnak a táblázatkezelő programok is, amelyek az irodai alkalmazások alapvető részét képezik.

A táblázatkezelőkben rendelkezésre álló szolgáltatások folyamatosan fejlődnek, illetve új képességek jelennek meg, amelyek frissítések, vagy új programverziók formájában válnak elérhetővé és így van ez a Microsoft Excel esetében is. A továbbfejlesztett, illetve új szolgáltatások igénybevételének alapvető feltételei: (1) az újdonságot be kell szerezni és (2) telepíteni kell, (3) az új szolgáltatások használatát meg tanulni és ezután válik lehetővé (4) a hatékony használatuk a döntések támogatása érdekében. A beszerzés sok esetben pénzbe kerül, a telepítés is körülményes lehet és újabb költségekkel járhat. A program használatának meg-, illetve újratanulása időigényes lehet és az autodidakta mód a felkínált szolgáltatások sokrétüsége miatt nem mindenki számára járható út, a szervezett betanítás viszont ismét újabb költséget jelent. Mindezek után sem garantált, hogy az adott döntéshozó hatékonyan fogja használni a táblázatkezelő szolgáltatásait (ha használja egyáltalán), mivel például lehet, hogy saját ösztöneiben jobban bízik, mint egy gépben (különösen, ha nem ismeri eléggé a program szolgáltatásait és korlátait, vagy nem megfelelő teljesítményü hardveren dolgozik). Azon kívül kérdés, hogy mit jelent a „hatékony” használat, hogyan és mivel mérhető az egy döntést támogató eszköz esetében: több hasznot hoz, mint amennyibe a beszerzése és használata kerül - de hogyan mérhető egzakt módon ebben az esetben a „haszon”?

A fentiek ellenére elmondható, hogy egy korszerü táblázatkezelő szolgálatatásainak ismerete előnyt biztosíthat a szervezeti döntéshozó számára, mert 
a biztosított eszközökkel a hagyományos (korszerütlen, ösztönökre, intuíciókra hagyatkozó) döntések helyett adatokra, információkra alapozott jobb döntések születhetnek.

\section{Irodalomjegyzék}

American Library Association (szerk.) (1989): Presidential Committee on Information Literacy: Final Report. Washington D. C. <https://www.ala.org/acrl/publications/whitepapers/presidential> (2021.05.04.)

Chikán A. (1978): Operációkutatás és döntéselmélet II. Müszaki Könyvkiadó, Budapest.

Computer History (n. a.): VisiCalc of Dan Bricklin and Bob Frankston <https://historycomputer.com/visicalc-of-dan-bricklin-and-bob-frankston/> (2021.05.04.)

ExcelDashboardSchool.com (2020): Financial Dashboard Template. $<$ https://exceldashboardschool.com/financial-dashboard-template/> (2021.05.04.)

Few, S. (2006): Information Dashboard Design. The Effective Visual Communication of Data. O’Reilly Media, Inc., Sebastopol.

Hampel Gy., Heves Cs. (2019): Informatika alapjai mérnököknek, alapszakos hallgatók számára. Szegedi Tudományegyetem, Szeged.

Hanyecz L. (1994): Döntéshozatal. Döntési modellek. Janus Pannonius Tudományegyetem Egyetemi Kiadó, Pécs.

Hanyecz L. (1995): Tervezés és stratégia. Janus Pannonius Tudományegyetem Egyetemi Kiadó, Pécs. Horváth I. (2002): Közigazgatási szervezés- és vezetéstan. Dialóg Campus Kiadó, Budapest-Pécs.

Juhász S. (2015): Vállalati információs rendszerek müszaki alapjai. Online Kiadás. Szak Kiadó, Bicske.

Kacsukné Bruckner Lívia, Kiss Tamás (2019): Bevezetés az üzleti informatikába: az e-korszak üzletembere számára. Online kiadás. Akadémiai Kiadó, Budapest. https://doi.org/10.1556/9789634544852

Kepos, P. (1994): International Directory of Company Histories, Vol. 9. St. James Press, Detroit, Mich.

Kindler J. (2006): A döntések világa. Harvard Business Manager, 8 (7-8): 28-35.

Kővári A. (2017): Dashboard fogalma. Blog. <https://www.biprojekt.hu/blog/Dashboardfogalma.htm> (2021.05.04.)

Pincher, A. C. (2021): 10 best spreadsheet software options to try in 2021. JotForm. $<$ https://www.jotform.com/blog/best-spreadsheet-software/> (2021.05.04.)

Power, D. J. (szerk.) (2004): A Brief History of Spreadsheets. DSSResources.COM $<$ http://www.dssresources.com/history/sshistory.html $>$ (2021.05.04.)

Power, D. J., Kaparthi Sh. (2003): Spreadsheets. In: Bidgoli, H. (szerk.): Encyclopedia of Information Systems. University of Northern Iowa, USA. 171-186. https://doi.org/10.1016/B0-12-2272404/00165-9

Sántáné-Tóth E., Bíró M., Gábor A., Kő A., Lovrics L. (2008): Döntéstámogató rendszerek. Panem Kiadó, Budapest.

WinWorld (n. a.): Microsoft Excel 1.x $<$ https://winworldpc.com/product/microsoft-excel/1x $>$ (2021.05.04.)

Youtube, Create and Learn (2016): Create beautiful Infographics in MS Excel for your dashboard $<$ https://www.youtube.com/watch?v=4W8Nh7kAZf8> (2021.04.10.)

Youtube, Faysal Easy Excel (2020): 3D Infographic Cylinder Chart in Excel 2016 $<$ https://www.youtube.com/watch? $\mathrm{v}=\mathrm{qOCLjzSyqDg}>(2021.04 .10$.

Youtube, Leila Gharani (2018): How to create a dynamic map chart with drop-down (works with ANY Excel version) <https://www.youtube.com/watch? $\mathrm{v}=$ EoKoN1q2cTk> (2021.04.10.)

Youtube, PK: An Excel Expert (2018): Conditional Formatting in Line Chart $<$ https://www.youtube.com/watch?v=WUCFn3EdeXc $>$ (2021.04.10.) 